\title{
A Co-operative Numerical Analysis of Rapidly Growing Mycobacteria
}

\author{
By G. P. KUBICA, ${ }^{1}$ INGA BAESS, ${ }^{2}$ RUTH E. GORDON,${ }^{3}$ P. A. JENKINS, ${ }^{*}$ \\ J. B. G. KWAPINSKI, ${ }^{5}$ CAROLYN MCDURMONT, ${ }^{6}$ S. R. PATTYN, \\ H. SAITO, ${ }^{8}$ VELLA SILCOX, ${ }^{9}$ J. L. STANFORD, ${ }^{10} \mathrm{~K}$. TAKEYA, ${ }^{11}$
} M. TSUKAMURA ${ }^{12}$

(Received 6 March 1972)

\section{SUMMARY}

A co-operative numerical taxonomic analysis of rapidly growing mycobacteria of Runyon's group IV is reported. There was no limitation on the number, nature, or method of performance of the test characters contributed by each of the 12 participants. Initially $4 \mathrm{I} 5$ test characters were coded for analysis; deletion of irrelevant and repetitious data resulted in a final 195 characters used to generate the matching matrix. All nine major clusters defined in the study were of named species; however, three of these were noted to contain two or more species and the reduction of some of these to synonymy with prior epithets is discussed. Recognized clusters were: Mycobacterium smegmatis, $M$. phlei, $M$. vaccae (including $M$. parafortuitum), $M$. diernhoferi, $M$. flavescens, the rhodochrous taxon, $M$. thamnopheos, $M$. fortuitum, $M$. chelonei. Results of the pooled information are compared with those of the individual participants. Immunological results generally correlated well with numerical analyses.

\section{INTRODUCTION}

The reports of Buhler \& Pollak (1953) and Crow et al. (1957) made it readily apparent that mycobacteria other than tubercle bacilli could produce a tuberculosis-like disease in man. To provide some systematic basis for discussion of these newly discovered microbes, Runyon (1959, 1965) described four groups of 'atypical' mycobacteria, and application of numerical taxonomic methods to a study of these organisms has demonstrated that each of Runyon's four groups contain several clearly distinct mycobacterial taxa (Bojalil, Cerbon \& Trujillo, 1962; Tsukamura, I966; Wayne, 1967; Kubica et al. 1970). To obtain international agreement on the precise definition of these new taxa, a number of mycobacteriologists organized themselves into an informal group, the International Working Group on Mycobacterial Taxonomy (IWGMT), one of whose major aims has been the co-operative, systematic examination of selected sets of mycobacteria, representative of the four groups of Runyon, to attempt to provide more exact species definitions.

\footnotetext{
1 Trudeau Institute, Inc., P.O. Box 59, Saranac Lake, New York 12983, U.S.A.

2 Statens Seruminstitut, Copenhagen, S. Denmark.

3 Rutgers, The State University, New Brunswick, New Jersey, U.S.A.

4 University Hospital of Wales, Cardiff, South Wales.

5 University of Manitoba, Winnipeg, Canada.

6 Department of Public Health, Montgomery, Alabama, U.S.A.

7 Instituut voor Tropische Greneeskunde, Antwerp, Belgium.

${ }^{8}$ Hiroshima University School of Medicine, Hiroshima, Japan.

9 Center for Disease Control, Atlanta, Georgia, U.S.A.

${ }_{10}$ Middlesex Hospital Medical School, London, England.

11 Kyushu University Medical School, Fukuoka, Japan.

12 Chubu Chest Hospital, Obu Chita-Gun Aichi-Ken, Japan.
} 
The first international co-operative study (Wayne et al. I97I) is followed by this second investigation, a study of rapidly growing mycobacteria by 12 different laboratories. The same 'permissive' philosophy (Wayne et al. 197I) was used here, i.e. each participant was allowed to do whatever tests he chose on the cultures; all investigators submitted their raw results to the study co-ordinator for collation and performance of numerical analyses on both in the pooled and individual information.

\section{METHODS}

Fifty cultures representative of Runyon's Group IV (Wayne, Runyon \& Kubica, I969) were selected from the collection of the Mycobacteriology Unit, Centerfor Disease Control, Atlanta, and sent to the American Type Culture Collection (ATCC) for lyophilization; in addition, I7 other strains from the ATCC were included for reference purposes. Samples of these 67 strains were returned to the laboratory of the first named author for confirmation of identity, following which the ATCC distributed these coded cultures to all study participants.

Each investigator performed his series of selected tests on the set of cultures received Results were sent to the co-ordinator, who coded as much of the information as possible into binary form for analysis. In the first analysis 4I 5 characters, of a non-immunological nature, were coded for each culture; these were submitted by 8 of the I 2 participants. In addition, results of serological comparisons, phage typing, skin test reactions, lipid patterns, and mouse pathogenicity were available for comparison with the initial numerical analysis. Following Wayne et al. (I97I), two types of result were deleted without changing the final results:

(I) Tests in which all strains gave the same reaction, i.e. either positive or negative, were deleted as irrelevant. Although these were of no value in the differential identification of rapidly growing mycobacteria, they have been stored for potential future use in the taxonomic separation of slowly growing from rapidly growing mycobacteria.

(2) Occasionally, when several investigators performed the same test, with essentially the same results, those from a single laboratory were selected and repetitious results thus eliminated to avoid weighting of these particular characters. In some cases two investigators utilized entirely different test conditions to measure the same property; when this resulted in markedly different final reactions, both sets of results were retained in the study.

Deletion of irrelevant and repetitious results left 195 characters which were analysed by a conventional $n \times n$ matrix table of matching scores with negative matches included. So that clusters obtained in the composite study could be compared with those attained by the individual participants, the data from each laboratory were individually subjected to numerical analyses, and the $n \times n$ diagrams were generated with the cultures printed out in the same order as for the pooled data. From the analysed data it was possible to tabulate certain selected properties which proved highly reliable in the differential identification of the clusters recognized in this investigation.

As before (Wayne et al. I97I), all participants agreed not to withdraw their data regardless of the final results or the interpretations placed upon them, and to retain anonymity of participants neither individual results nor details of techniques are presented. After completion of other studies now in progress, it is hoped that details of those tests which have proved most definitive may be presented as a list of standard methods for both taxonomic and determinative studies on mycobacteria. 

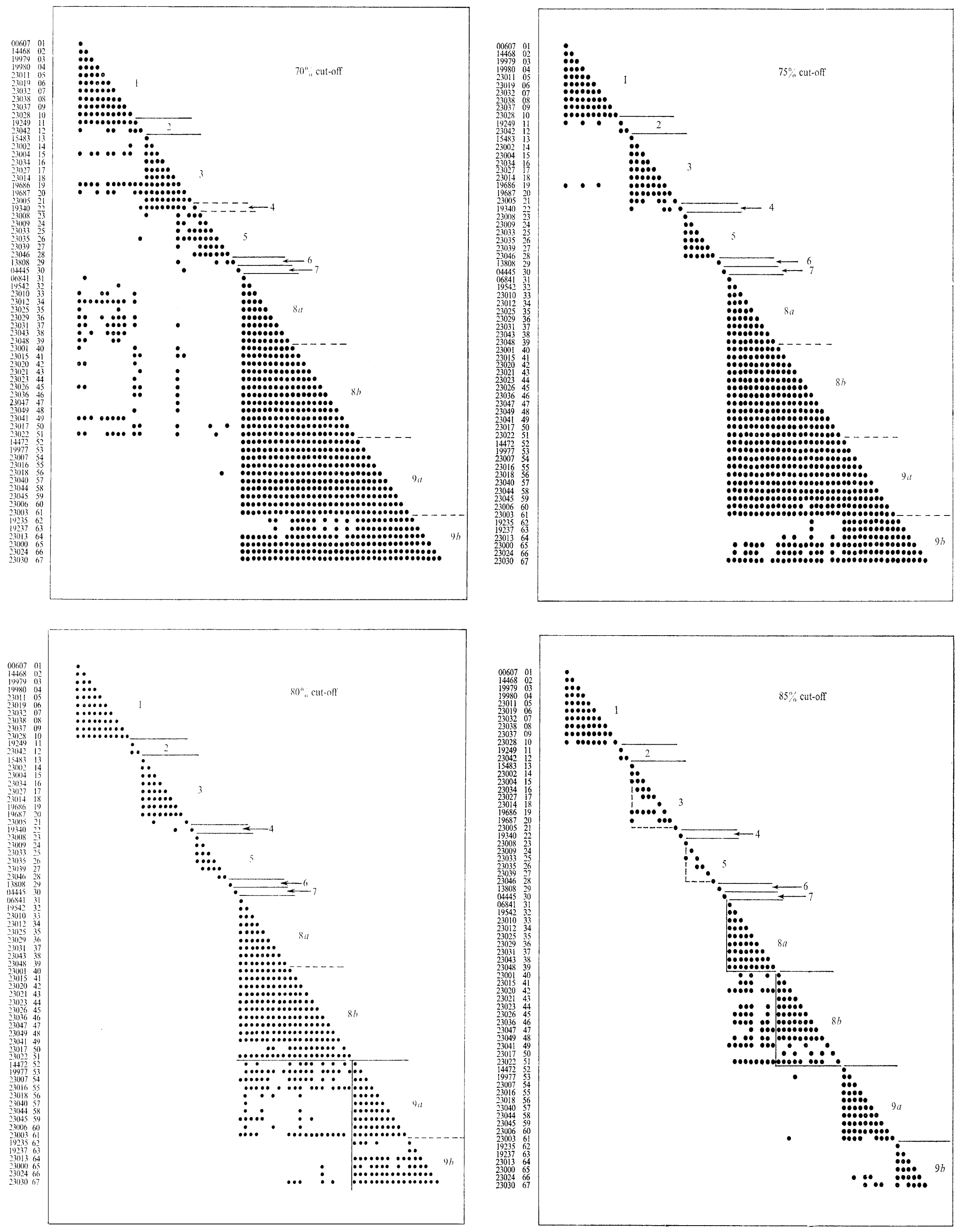

Fig. I. (b) Evolution of clusters from Fig. I (a) at the 70-75-80-85\% matching score levels. 


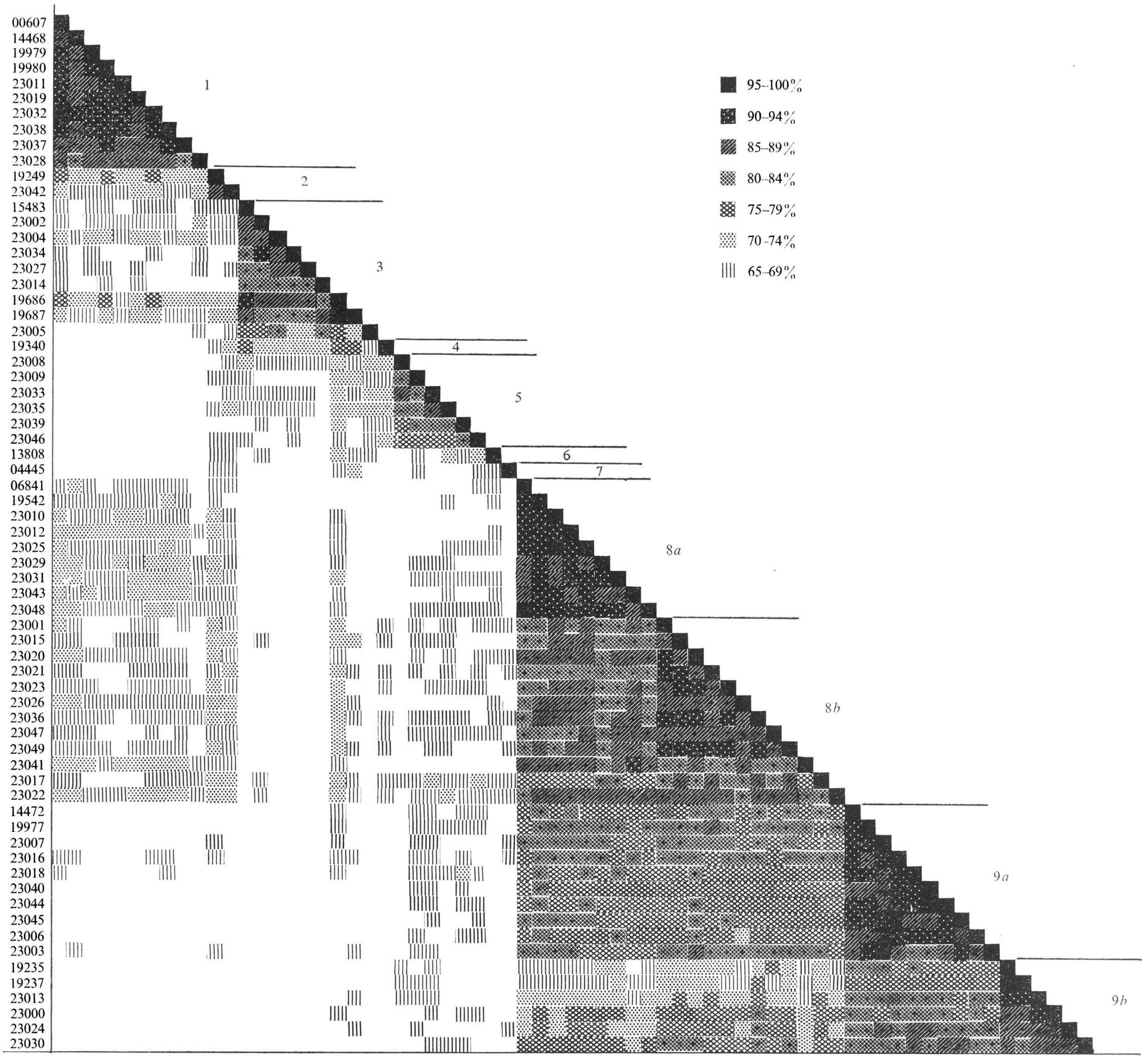

Fig. I. (a) Matching matrix of 67 strains of rapidly growing mycobacteria based on 195 pooled characters. 


\section{RESULTS}

Fig. I (a) reveals the clusters obtained by analysis of the 195 characters generated from the pooled data, while Fig. I $(b)$ depicts the development of these clusters over a range from $70 \%$ to $85 \%$ similarity. Eleven clusters were separated at the $85 \%$ level or higher; however, at the $80 \%$ level, four of these clusters joined to form two, yielding nine distinct clusters.

Cluster I contains ten strains with an internal similarity of $90 \%$. Internal similarity here is defined as the highest intracluster matching score shown by $>50 \%$ of strain pairs in the cluster. The suggested neotype of Mycobacterium smegmatis, ATCC 14468, is one of these strains.

Cluster 2 contains two strains at a $90 \%$ internal similarity, both identified as $\mathrm{Myco}$ bacterium phlei. One of these, ATCC 19249 , is identical with ATCC I I 758 and NCTC 8I 5 I, the suggested 'working type' of the species (Sneath \& Cowan, 1958, p. 555).

Cluster 3 consists of nine strains, with an internal similarity of $85 \%$, which were representative of the two taxa, Mycobacterium vaccae (Bönicke \& Juhasz, I964) and M. parafortuitum (Tsukamura, Toyama \& Mizuno, 1965). Although these two taxa have been reported to be distinct (Tsukamura, Mizuno \& Tsukamura, 1968), neither the pooled data nor the results of any individual investigator were clearly able to separate them when the organisms were treated as unknowns. The type strains of $M$. vaccae (ATCC I5483) and M. parafortuitum (ATCC 19686) were included in this study. This cluster will be further dealt with in the Discussion.

Clusters 4, 6 and 7 respectively contain only one strain each of Mycobacterium diernhoferi (type culture ATCC 19340), the rhodochrous taxon (ATCC I3808) and $M$. thamnopheos (type culture ATCC 4445). These were included for comparative purpose only, and they appeared quite unlike any of the other clusters in this investigation.

Cluster 5, with an internal similarity of $83 \%$, contains six strains equated with $\mathrm{Myco-}$ bacterium flavescens. Unfortunately the type culture of Bojalil et al. (1962) was not included in this study, but the detailed description of this species (Bojalil et al. 1962; Wayne, Doubek \& Diaz, 1967) matches that of the organisms in this cluster, and the participants are in accord that this group of organisms is representative of $M$. flavescens.

Cluster 8 contains two closely related subclusters. The subgroup $8 a$, with a $90 \%$ internal similarity, contains the type culture of Mycobacterium fortuitum, strain ATcC684I. Subcluster $8 b$, with an $85 \%$ internal similarity, contains Bojalil's strain 6020 (coded as 23023), which is the type strain of M.peregrinum (ATCC I 4467). At $80 \%$ similarity these two clusters are virtually homogeneous (see Fig. I b). The name of this taxon will be dealt with in the Discussion.

Cluster 9 is comprized of two closely related groups of organisms. Subgroup $9 a$, internal similarity $90 \%$, contains the type cultures of Mycobacterium abscessus (ATCC 19977) and $M$. runyonii (ATCC I4472). Subcluster $9 b$, internal similarity $85 \%$, contains the type strain of $M$. borstelense (ATCC 19235). These two taxa join at the $80 \%$ level of similarity (see Fig. I $b$ ). The suggested name of this taxon also will be discussed later.

Since the computer had printed out matching matrices for each laboratory in $5 \%$ increments from 65 to $95 \%$, it was considered sufficient for this report to record individual matching matrices (Fig. $2 a-h$ ) only to the nearest $5 \%$. In each instance in Fig. 2, the interor intracluster scores indicate the percentage similarity to the lowest $5 \%$. The actual score could either equal this value or exceed it by no more than 4 percentage points. For example, in Fig. $2(a)$ the intrataxon values of Mycobacterium smegmatis and $M$. phlei respectively were 85 and $90 \%$. The intertaxon relationship of these two species is listed as $70 \%$, which 
(a) Laboratory A. 55 characters

\begin{tabular}{|c|c|c|c|c|c|c|c|c|c|c|c|}
\hline $\begin{array}{l}\text { Cluster } \\
\text { Name }\end{array}$ & 1 & 2 & 3 & 4 & 5 & 6 & 7 & $8 a$ & $8 b$ & $9 a$ & $9 b$ \\
\hline M. smegmatis 1 & & 17 & 19 & & $>19$ & & & $>19$ & $>19$ & $>19$ & $>19$ \\
\hline M. phlei 2 & 70 & & 14 & & 17 & & & 14 & 14 & 19 & 19 \\
\hline M. vaccae 3 & 65 & 75 & & & 19 & & & 17 & 17 & $>19$ & $>19$ \\
\hline M. diernhoferi 4 & & & & & & & & & & & \\
\hline M. flavescens & - & 70 & 65 & & & & & 17 & 17 & 19 & 19 \\
\hline M. rhodochrous 6 & & & & & & & & & & & \\
\hline 1. thamnopheos 7 & & & & & & & & & & & \\
\hline M. fortuitum $8 a$ & - & 75 & 70 & & 70 & & & & 8 & 14 & 11 \\
\hline M. peregrinum $8 b$ & - & 75 & 70 & & 70 & & & 85 & & 14 & 17 \\
\hline M. abscessus $9 a$ & - & 65 & - & & 65 & & & 75 & 75 & & 8 \\
\hline M. horstelense $9 b$ & - & 65 & - & & 65 & & & 80 & 70 & 85 & \\
\hline
\end{tabular}

(b) Laboratory B, 80 characters

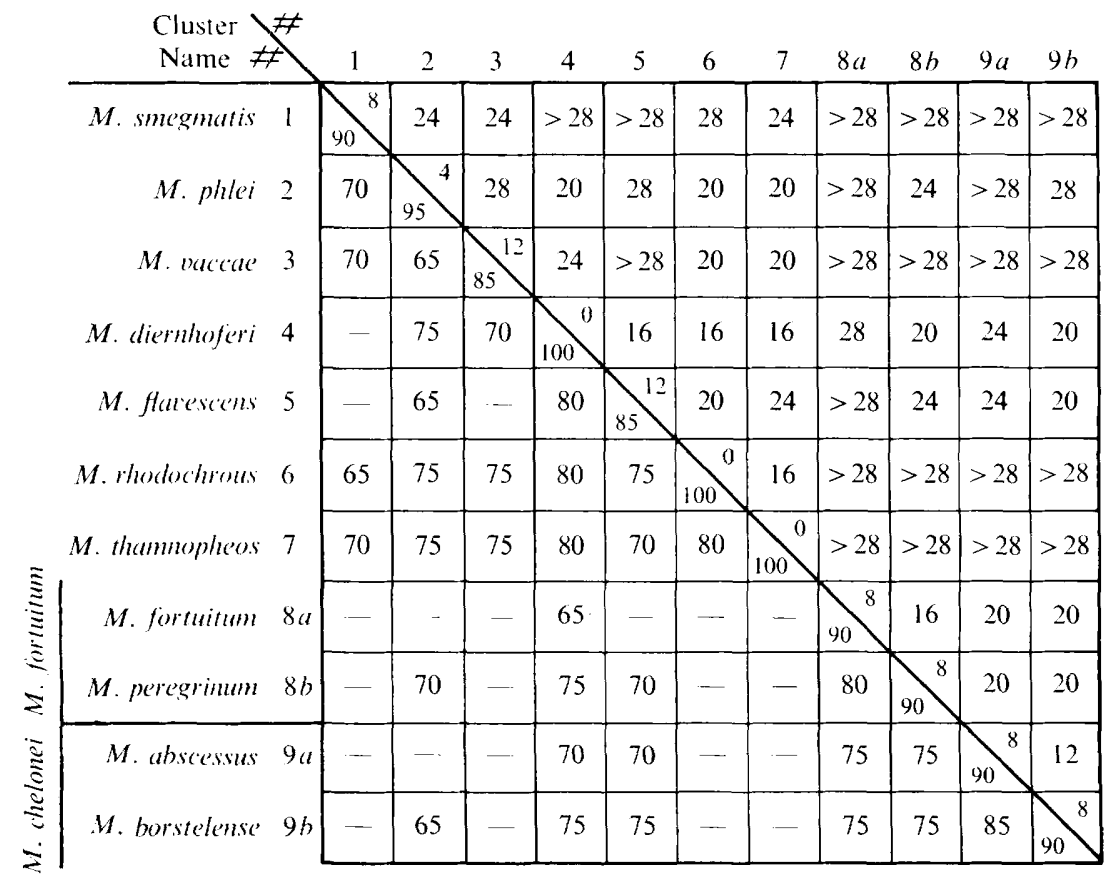

Fig. 2. (a,b) Matching scores to lowest $5 \%$ (below and left of diagonal) and number of characters' median difference for intra- and intertaxon clusters (above and to right of diagonal) of rapidly growing mycobacteria as determined from data from individual participating laboratories. For any square without a number, that cluster (usually a single strain) was not examined by the laboratory in question. A dash in any square below and left of the diagonal indicates the matching score was less than $65 \%$. Laboratories are identified only by code letters A-H (see also Fig. $2 c-h$ ). 
(c) Laboratory C. 58 characters

\begin{tabular}{|c|c|c|c|c|c|c|c|c|c|c|c|c|}
\hline $\begin{array}{l}\text { Cluster } \\
\text { Name }\end{array}$ & & 1 & 2 & 3 & 4 & 5 & 6 & 7 & $8 a$ & $8 b$ & $9 a$ & $9 b$ \\
\hline M. smegmatis & 1 & 1 & 18 & 15 & 21 & $>21$ & $>21$ & $>21$ & $>21$ & $>21$ & $>21$ & $>21$ \\
\hline M. phlei & 2 & 70 & & 18 & 18 & 21 & 21 & 18 & $>21$ & $>21$ & $>21$ & $>21$ \\
\hline M. raccue & 3 & 75 & 70 & 6 & 15 & 21 & 21 & 18 & 21 & 21 & $>21$ & $>21$ \\
\hline M. diernhoferi & 4 & 65 & 70 & 75 & 10010 & 15 & 21 & 21 & 21 & 21 & 21 & 21 \\
\hline M. Hutescens & 5 & - & 65 & 65 & 75 & & 21 & 21 & 21 & 21 & 21 & 21 \\
\hline M. rhodochrous & 6 & $\ldots$ & 65 & 65 & 65 & 65 & & 21 & $>21$ & $>21$ & $>21$ & $>21$ \\
\hline M. thamnophess & 7 & - & 70 & 70 & 65 & 65 & 65 & & 21 & 21 & 21 & 21 \\
\hline$M$. fortuitum & $8 a$ & - & & 65 & 65 & 65 & - & 65 & & 6 & 6 & 6 \\
\hline M. peregrinum & $8 b$ & & - & 65 & 65 & 65 & & 65 & 90 & & 9 & 6 \\
\hline M. abscessus & $9 a$ & - & - & - & 65 & 65 & - & 65 & 90 & 85 & & 6 \\
\hline$M$. horstelense & $9 b$ & - & - & & 65 & 65 & - & 65 & 90 & 90 & 90 & \\
\hline
\end{tabular}

(d) Laboratory D. 11 characters

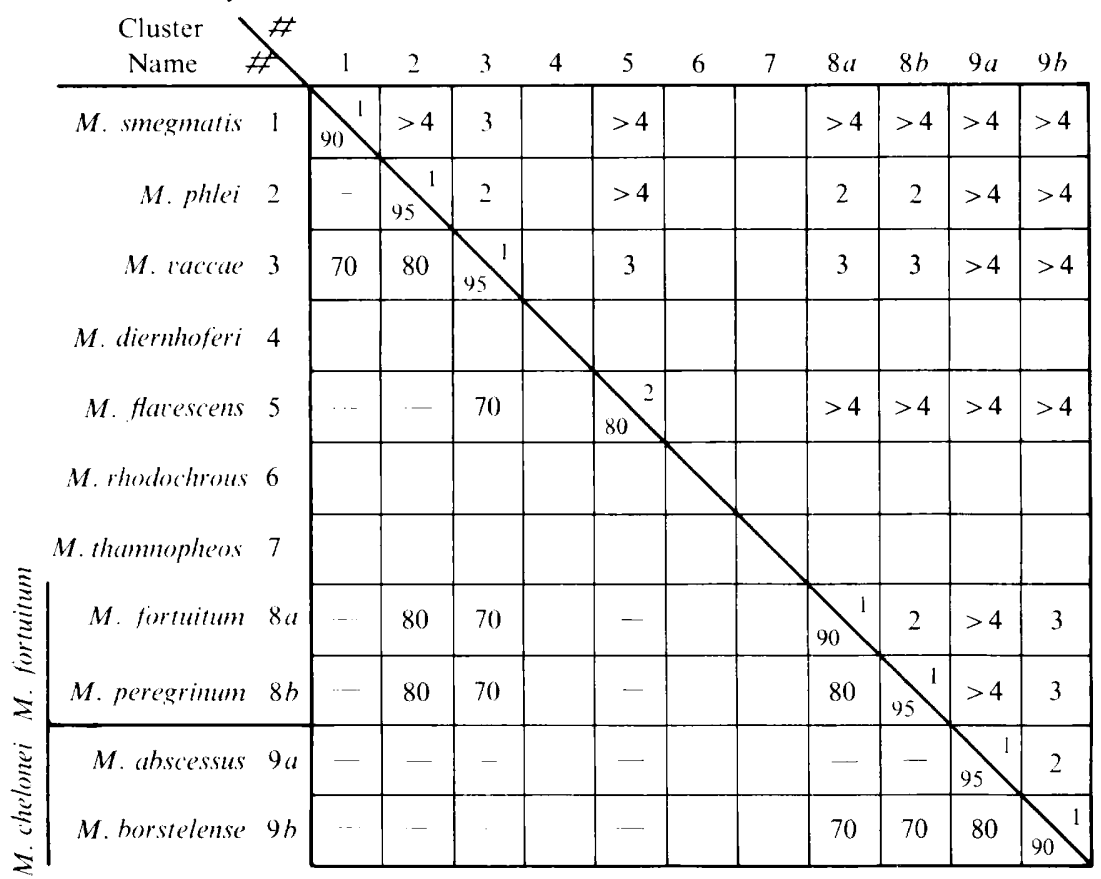

Fig. 2. (c, d) For legend see Fig. $2(a, b)$. 
(e) Laboratory E, 49 characters

\begin{tabular}{|c|c|c|c|c|c|c|c|c|c|c|c|c|}
\hline $\begin{array}{c}\text { Cluster } \\
\text { Name }\end{array}$ & & 1 & 2 & 3 & 4 & 5 & 6 & 7 & $8 a$ & $8 b$ & $9 a$ & $9 h$ \\
\hline M. smegmatis & 1 & & 10 & 12 & 15 & $>17$ & $>17$ & $>17$ & 17 & 17 & $>17$ & $>17$ \\
\hline M.phlei & 2 & 80 & & 10 & 7 & 12 & 12 & 17 & 12 & 12 & 15 & 15 \\
\hline M. vaccae & 3 & 75 & 80 & & 12 & 15 & 12 & 17 & 15 & 12 & 17 & 17 \\
\hline M. diernhoferi & 4 & 70 & 85 & 75 & & 12 & 17 & 17 & 12 & 12 & 12 & 12 \\
\hline M. flavescens & 5 & - & 75 & 70 & 75 & & 12 & 15 & 12 & 12 & 12 & 12 \\
\hline M. rhodochrous & 6 & - & 75 & 75 & 65 & 75 & 100 & 15 & 17 & 17 & 17 & 17 \\
\hline M. thamnopheos & 7 & - & 65 & 65 & 65 & 70 & 70 & 0 & 17 & 12 & 17 & 17 \\
\hline$M$. fortuitum & $8 a$ & 65 & 75 & 70 & 75 & 75 & 65 & 65 & & 5 & 7 & 5 \\
\hline$M$. peregrinum & $8 b$ & 65 & 75 & 75 & 75 & 75 & 65 & 75 & 90 & & 7 & 7 \\
\hline M. abscessus & $9 a$ & 一 & 70 & 65 & 75 & 75 & 65 & 65 & 85 & 85 & & 5 \\
\hline$M$. borstelense & $9 b$ & - & 70 & 65 & 75 & 75 & 65 & 65 & 90 & 85 & 90 & \\
\hline
\end{tabular}

(f) Laboratory F, 10 characters

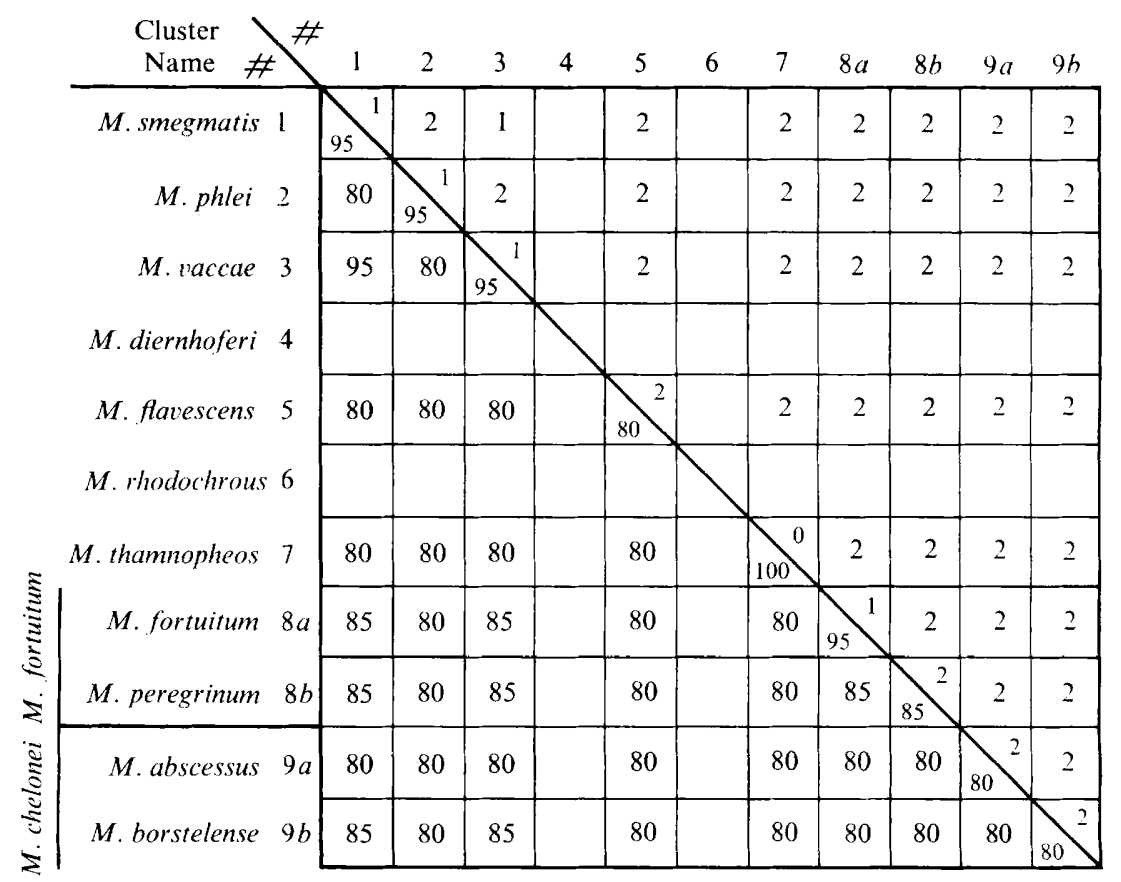

Fig. 2. $(e, f)$ For legend see Fig. $2(a, b)$. 
(g) Laboratory G. 53 characters

\begin{tabular}{|c|c|c|c|c|c|c|c|c|c|c|c|}
\hline $\begin{array}{c}\text { Cluster } \\
\text { Name }\end{array}$ & $F$ & 2 & 3 & 4 & 5 & 6 & 7 & $8 a$ & $8 b$ & $9 a$ & $9 b$ \\
\hline M. smegmatis 1 & 1 & 13 & 13 & 16 & 16 & 16 & & 13 & 13 & 16 & 19 \\
\hline M.phlei 2 & 75 & & 16 & 19 & 16 & 16 & & 19 & 19 & 19 & $>19$ \\
\hline M. raccae 3 & 75 & 70 & 11 & 13 & 11 & 16 & & 19 & 19 & $>19$ & $>19$ \\
\hline M. diernhoferi 4 & 70 & 65 & 75 & 00 & 13 & 19 & & $>19$ & $>19$ & $>19$ & $>19$ \\
\hline M. Hawescens 5 & 70 & 70 & 80 & 75 & & 16 & & $>19$ & $>19$ & $>19$ & $>19$ \\
\hline M. rhodochrous 6 & 70 & 70 & 70 & 65 & 70 & & & 19 & 19 & $>19$ & $>19$ \\
\hline M. thamnopheos 7 & & & & & & & & & & & \\
\hline M. fortuitum $8 a$ & 75 & 65 & 65 & & - & 65 & & & 8 & 11 & 13 \\
\hline M. peregrinum $8 \mathrm{~h}$ & 75 & 65 & 65 & & -.. & 65 & & 85 & & 11 & 13 \\
\hline M. abscessus 9a & 70 & 65 & & & - & & & 80 & 80 & & 11 \\
\hline M. borstelense $9 h$ & 65 & - & & & - & - . & & 75 & 75 & 80 & \\
\hline
\end{tabular}

(h) Laboratory H. 99 characters

\begin{tabular}{|c|c|c|c|c|c|c|c|c|c|c|c|c|}
\hline $\begin{array}{c}\text { Cluster } \\
\text { Name }\end{array}$ & & 1 & 2 & 3 & 4 & 5 & 6 & 7 & $8 a$ & $8 b$ & $9 a$ & $9 b$ \\
\hline M. smegmatis & 1 & & 20 & $>35$ & $>35$ & $>35$ & $>35$ & 35 & 30 & 30 & $>35$ & $>35$ \\
\hline M. phlei & 2 & 80 & & $>35$ & 35 & $>35$ & $>35$ & $>35$ & 30 & 30 & 35 & $>35$ \\
\hline M. vaccae & 3 & - & $\ldots$ & S & 25 & 35 & $>35$ & 35 & $>35$ & $>35$ & $>35$ & $>35$ \\
\hline M. diernhoferi & 4 & -- & 65 & 75 & & 30 & $>35$ & $>35$ & $>35$ & 35 & $>35$ & 35 \\
\hline M. flavescens & 5 & - & $\ldots$. & 65 & 70 & 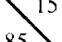 & 30 & 30 & 35 & 35 & 30 & 25 \\
\hline M. rhodochrous & 6 & - & $\ldots$ & & - & 70 & & 35 & 25 & 30 & 30 & 35 \\
\hline ir. thamnopheos & 7 & 65 & - & 65 & - - & 70 & 65 & & 25 & 25 & 25 & 35 \\
\hline M. fortuitum & $8 a$ & 70 & 70 & & -.- & 65 & 75 & 75 & & 15 & 20 & 30 \\
\hline$M$. peregrinum & $8 b$ & 70 & 70 & & 65 & 65 & 70 & 75 & 85 & & 20 & 30 \\
\hline M. abscessus & $9 a$ &.- & 65 & & - & 70 & 70 & 75 & 80 & 80 & & 25 \\
\hline M. horstelense & $9 h$ & - & - & - & 65 & 75 & 65 & 65 & 70 & 70 & 75 & \\
\hline
\end{tabular}

Fig. 2. $(g, h)$ For legend see Fig. $2(a, b)$. 
Table I. Distribution of characters with greatest resolving power for rapidly growing mycobacteria*

Cluster no. and species

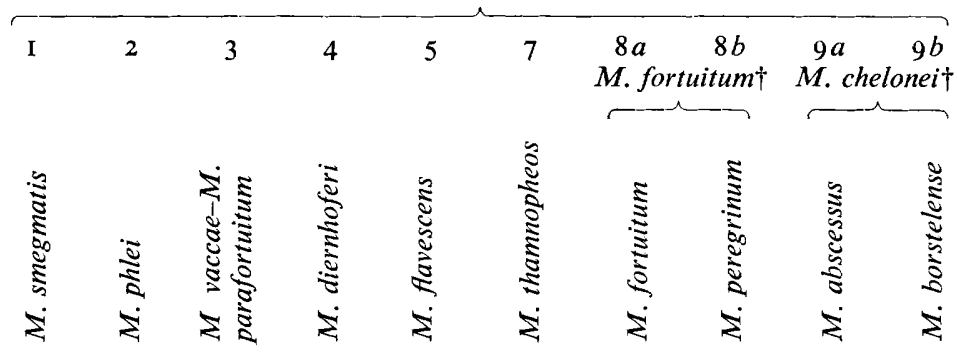

\section{Pigment}

In dark

Photoactive

$$
0100 \quad 100
$$

Enzymatic activity

Acid phosphatase

(see test no. 45)

Arylsulphatase, 3 day

Arylsulphatase, 2 week

Hippurate hydrolysis

Nitrate reductase

Tween hydrolysis, 5 day

Tween opacity, I week

Tween opacity, 5 week 10

Growth

In $<5$ days

At $42^{\circ} \mathrm{C}$

At $45^{\circ} \mathrm{C}$

At $52{ }^{\circ} \mathrm{C}$

After $60^{\circ} \mathrm{C} / 4 \mathrm{~h}$

On single carbon source

Benzoate

Citrate

Malonate

Mucate (or oxalate)

Propanol 20

No. $\dot{z}$

On single nitrogen source

Acetamide

Nicotinamide

Nitrite

On single nitrogen/ carbon source

Acetamide

Benzamide

Trimethylenediamine

I

In presence of

I $\%$ deoxycholate

$5 \% \mathrm{NaCl}$

MacConkey agar

Methyl violet

$3 \quad 0 \quad 100 \quad 12$

$4 \quad 10$

$5 \quad 100$

$10 \quad 0$

$100 \quad 50$

$0 \quad 100$

$7 \quad 100 \quad 100$

$8 \quad 100$

100

$100 \quad 100 \quad 75$

100

100

I 00

$\begin{array}{rr}0 & 83 \\ 0 & 0\end{array}$

83
0

$100 \quad 16$

0
0
100
100
100

0
67
33
100
100

$\begin{array}{rr}0 & 100 \\ 0 & 100 \\ 0 & 100 \\ 100 & 100\end{array}$

100

IOO

100

$\begin{array}{lll}100 & 55 & 58\end{array}$

100
100

83
100

o

55
100

83
100

$100 \quad 100$

88

100

100

100

100

0
16
0
0
0

$100 \quad 100$

$\begin{array}{ll}0 & 100 \\ 0 & 0\end{array}$

100

o 100

0

0
0

$0 \quad 0$

0

0

$\begin{array}{rr}0 & 0 \\ 0 & 0 \\ 100 & 100 \\ & \\ 100 & 100 \\ 100 & 100 \\ 80 & 100 \\ 0 & 17 \\ 30 & 0 \\ 100 & 33 \\ 100 & 100 \\ & \\ 100 & 100 \\ 0 & 0 \\ 0 & 0 \\ 0 & 0 \\ 0 & 0\end{array}$

I $6 \quad 100$

100
100

0

100

$\begin{array}{rr}0 & 16 \\ 100 & 0 \\ 0 & 0 \\ 0 & 0 \\ 100 & 83\end{array}$

0
100
0
0
0

$\begin{array}{rrrr}0 & 0 & 0 & 0 \\ 100 & 100 & 20 & 100 \\ 0 & 0 & 0 & 0 \\ 0 & 0 & 0 & 0 \\ 100 & 100 & 10 & 0\end{array}$

Pyronin B

I 00

100

100

100

66

100

100

100
100

IOO

100

100

Degradation of

$p$-Aminobenzoate

$\begin{array}{rr}100 & 100 \\ 100 & 0 \\ 100 & 100 \\ & \\ 100 & 100 \\ 100 & 100 \\ 0 & 0 \\ 80 & 0 \\ 100 & 0\end{array}$

100
0

0
0
14

0
0
100

0
0
0

0
0
100

100
0
100

50
0

0

$100 \quad 100$

o

Salicylate 
Table I (cont.)

\begin{tabular}{|c|c|c|c|c|c|c|c|}
\hline \multicolumn{8}{|c|}{ Cluster no. and species } \\
\hline 1 & 2 & 3 & 4 & 5 & 7 & $\begin{array}{cc}8 a & 8 b \\
\text { M. fortuitum } \dagger\end{array}$ & $\begin{array}{c}9 a \quad 9 b \\
\text { M. chelone } i \dagger\end{array}$ \\
\hline
\end{tabular}

Tests

Acid production from sugars

Arabinose

Dulcitol

Fructose

Galactose

Inositol

Mannitol

Rhamnose

Sorbitol

Sucrose

Xylose

Iron uptake

Acid phosphatase, $70^{\circ} \mathrm{C} / 30 \mathrm{~min}$
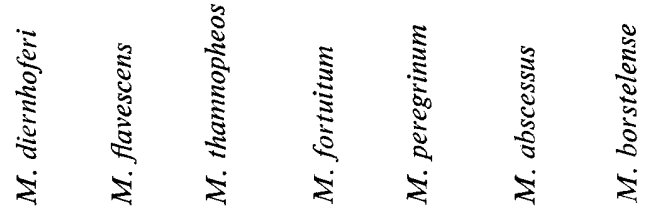

* Figures indicate percentage of strains exhibiting character. In the case of clusters 4 and 7 only one strain of each was studied.

$\dagger$ See Discussion.

Table 2. Distribution of cultures in clusters I, 2, 3, 5, 8, 9 in terms of source and clinical significance*

Number of strains in cluster no.

\begin{tabular}{|c|c|c|c|c|c|}
\hline & & & & & $\stackrel{9}{9}$ \\
\hline $\begin{array}{c}\text { I } \\
\text { smegmatis) }\end{array}$ & $\left(M \cdot{ }^{2}\right.$ phlei $)$ & $\begin{array}{c}3 \\
\text { (M. vaccae })\end{array}$ & $\stackrel{5}{\text { (M. flavescens) }}$ & $\begin{array}{c}8 \\
\text { (M. fortuitum) }\end{array}$ & (M. abscessus) (M. borstel \\
\hline$-/ 2$ & $-/ \mathrm{I}$ & . & . & $-1 / 2$ & . \\
\hline$? / 7$ & $? / \mathrm{I}$ & . & . & $2 / 7$ & . \\
\hline . & . & $-? / 6$ & . & $? / \mathrm{I}$ & . \\
\hline$-/ I$ & . & $-/ \mathbf{I}$ & $? / 6$ & 8/I I & $9 / 10$ \\
\hline
\end{tabular}

In each instance, the denominator indicates total number of strains and the numerator indicates the number thought to be clinically significant.

means the actual value could be 70 , but not more than $74 \%$. Because this study generated nine distinct clusters, it would be too complicated to prepare a composite table of the number of characters of intra- and intertaxon difference as was done in the earlier study (Wayne et al. 1971), where only two major clusters were observed. Thus, for comparison, the numbers below and to the left of the diagonal in each individual matching matrix in Fig. 2 represent the intra- and intercluster scores to the lowest $5 \%$; the numbers above and to the right of the diagonals represent both intra- and intercluster median number of different characters. The median number of intrataxon character differences (i.e. those 


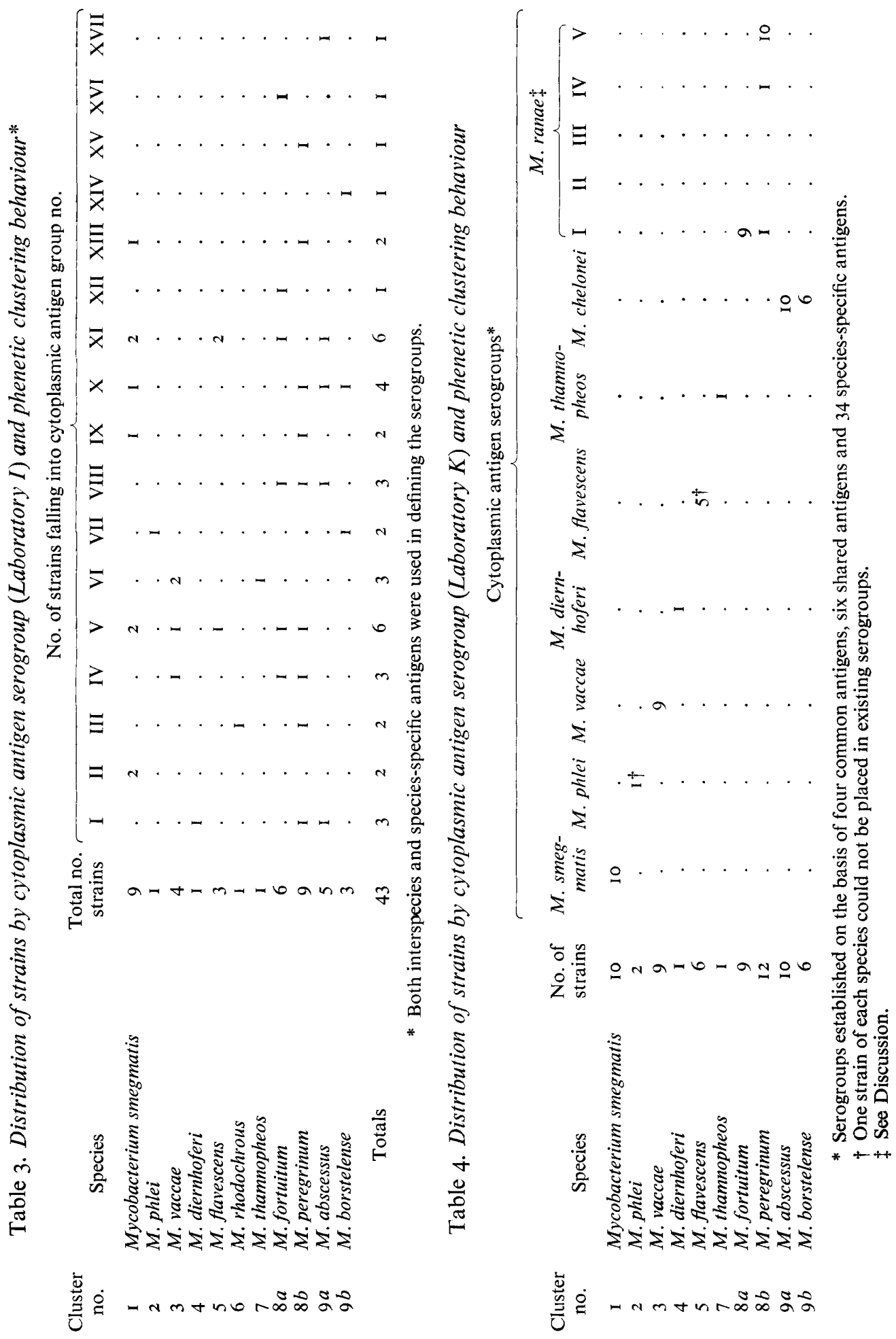


Table 5. Observed pathological changes in mice infected with organisms in the phenetic clusters

\begin{tabular}{|c|c|c|c|c|c|}
\hline \multirow[b]{2}{*}{$\begin{array}{c}\text { Cluster } \\
\text { no. }\end{array}$} & \multirow[b]{2}{*}{ Species } & \multirow[b]{2}{*}{$\begin{array}{l}\text { No. of } \\
\text { strains }\end{array}$} & \multicolumn{3}{|c|}{ Observation } \\
\hline & & & $\begin{array}{l}\text { Spinning } \\
\text { disease }\end{array}$ & $\begin{array}{l}\text { Gross } \\
\text { disease }\end{array}$ & $\begin{array}{l}\text { Positive } \\
\text { cultures }\end{array}$ \\
\hline I & Mycobacterium smegmatis & 10 & $5 / 10$ & $5 / 10$ & $5 / 10$ \\
\hline 2 & M. phlei & 2 & 0 & 0 & $\mathrm{I} / 2$ \\
\hline 3 & M. vaccae & 9 & 0 & 0 & 0 \\
\hline 4 & M. diernhoferi & i & 0 & 0 & 0 \\
\hline 5 & M. flavescens & 6 & $\mathrm{I} / 6$ & 0 & $1 / 6$ \\
\hline 6 & $M$. rhodochrous & 1 & 0 & o & o \\
\hline 7 & M. thamnopheos & I & 0 & 0 & 0 \\
\hline $8 a$ & $M$. fortuitum & 9 & $9 / 9$ & $8 / 9$ & $8 / 9$ \\
\hline $8 b$ & $M$. peregrinum & 12 & $1 / 12$ & $2 / 12$ & $2 / 12$ \\
\hline $9 a$ & M. abscessus* & 10 & $4 / 10$ & $9 / 10$ & $9 / 10$ \\
\hline $9 b$ & M. borstelense & 6 & 0 & o & $1 / 6$ \\
\hline
\end{tabular}

characters listed along the diagonal of Fig. $2 a-h$ ) reflects what Wayne et al. (I97I) referred to as intracluster 'noise' levels.

The number of characters employed by the individual participants ranged from Io to 99 . Results from individual laboratories yielded clusters in general agreement with that provided by the pooled data. With the exception of data for one cluster from one laboratory (Fig. $2 h$ ), all intracluster scores exceeded $80 \%$. The intercluster scores, on the other hand, ranged from less than $65 \%$ to greater than $95 \%$. Careful examination of the individual data revealed that those participants who had high intertaxon similarities either employed tests of greater value for separating slowly growing mycobacteria, but of lesser differential value for the rapidly growing acid-fast bacilli in this study, or used only a few tests of value for rapid growers, but totally masked these differential tests by the addition of many more irrelevant characters.

Examination of the individual properties of this collective group of rapidly growing mycobacteria revealed a number of common characteristics which may be valuable in separating these taxa from the slowly growing mycobacteria: all are niacin-negative, except for occasional strains of Mycobacterium borstelense var. niacinogenes; strains of all taxa are fully mature in 5 to 7 days, except for $M$. flavescens which has a growth rate intermediate between that of the rapidly growing and slowly growing acid-fast bacilli; all strains produced acid from glucose, but no acid from lactose, raffinose, melibiose, inulin or $\alpha$-methyl-Dglucoside; all possess urease activity; all rapid growers can utilize as carbon sources acetate, pyruvate, propionate, lactate and (except for some strains of $M$. flavescens) succinate; with the exception of the rhodochrous taxon, none of the rapid growers could decompose casein, adenine, hypoxanthine or tyrosine; all grow in the presence of nicotinamide, except $M$. thamnopheos; all grow at both $22^{\circ} \mathrm{C}$ and $37^{\circ} \mathrm{C}$.

Table I lists the reactions of eight recognized clusters in a series of 45 test characters, selected from the total of 195 characters as being most definitive in separation of these taxa. The rhodochrous taxon has been eliminated from this Table because it is accepted that these organisms are a heterogeneous assemblage; in fact, representatives of this taxon are currently the subject of a co-operative IWGMT study.

Table 2 summarizes the source and indicated clinical significance of those organisms in clusters $1,2,3,5,8$ and 9 for which information is available; the potential pathogens for man are located in clusters 8 and 9. Clinical laboratories should, therefore, be able quickly 
Table 6. Distribution of strains by phage typing patterns and phenetic clustering behaviour

\begin{tabular}{|c|c|c|c|c|c|c|c|c|c|}
\hline \multirow{2}{*}{$\begin{array}{c}\text { Cluster } \\
\text { no. }\end{array}$} & \multirow[b]{2}{*}{ Species } & \multirow{2}{*}{$\begin{array}{l}\text { No. of } \\
\text { strains }\end{array}$} & \multicolumn{7}{|c|}{ No. of strains having observed phage pattern* } \\
\hline & & & I & 2 & 3 & 4 & 5 & 6 & 7 \\
\hline I & Mycobacterium smegmatis & 9 & I & 5 & 3 & . & . & . & . \\
\hline 2 & M. phlei & I & . & . & . & I & . & . & . \\
\hline 3 & M. vaccae & 8 & 2 & . & . & . & 6 & . & . \\
\hline 4 & M. diernhoferi & I & . & . & . & . & I & . & . \\
\hline 5 & M. flavescens & 6 & 3 & . & . & . & . & 3 & . \\
\hline 6 & M. rhodochrous & I & I & . & . & . & . & . & . \\
\hline $8 a$ & M. fortuitum & 8 & 3 & . & . & . & . & 5 & . \\
\hline $8 b$ & M. peregrinum & 12 & 7 & . & . & . & . & 3 & 2 \\
\hline $9 a$ & M. abscessus & 10 & 5 & . & . & . & . & 5 & . \\
\hline $9 b$ & M. borstelense & 6 & 6 & . & . & . & . & . & . \\
\hline & * Patterns to phages & $\mathrm{D}_{4}$ & BK 3 & D I I & $\mathrm{BK}_{4}$ & D 30 & B 5 & & \\
\hline & I & 0 & 0 & 0 & 0 & 0 & 0 & & \\
\hline & 2 & 0 & + & 0 & \pm & 0 & 0 & & \\
\hline & 3 & + & + & 0 & + & 0 & + & & \\
\hline & 4 & 0 & 0 & + & 0 & 0 & 0 & & \\
\hline & 5 & 0 & 0 & 0 & 0 & 0 & + & & \\
\hline & 6 & 0 & 0 & 0 & + & 0 & 0 & & \\
\hline & 7 & 0 & 0 & 0 & + & 0 & + & & \\
\hline
\end{tabular}

to identify organisms in these two clusters, without the necessity of making a precise taxonomic characterization. Tests 4 (3-day arylsulphatase), 29 (growth on MacConkey's agar) and 33 (degradation of salicylate) seem to satisfy this need by clearly separating clusters 8 and 9 (positive in all three tests) from the other clusters (all negative). In addition, tests I $8,30,31,32,34,37$ and 45 may be of additional confirmatory value.

Correlation of immunological tests, phage typing, lipid patterns and mouse pathogenicity with the computer-generated clusters is summarized in Tables 3 to 7 . Only Laboratory D reported on the specificity of delayed type skin reactions to a trichloroacetic acid-precipitated protein injected intradermally into guinea pigs previously sensitized by injection of heat-killed test organisms suspended in paraffin oil. Unfortunately, because of time limitation, only the type strains in each cluster could be examined. However, the computer-sorted clusters were precisely duplicated in the I4 strains selected for delayed hypersensitivity testing (Takeya, Nakayama \& Muraoka, 1970). Only Mycobacterium flavescens and $M$. peregrinum were not examined by this method because neither of these species was represented by a type culture.

Cytoplasmic antigen serogrouping was performed by two laboratories. For these studies the soluble portion of mycobacterial lysates was tested in immunodiffusion tests with selected antisera (Stanford \& Beck, I968; Kwapinski, Alcasid \& Palser, 1970).

Laboratory I was able to define I 7 different serogroups (Table 3). Two of these serogroups (V and XI) had six strains each, while the remaining 15 had from one to four cultures. There seemed to be no localization of species into any one serogroup; in fact, several of the serogroups contained three or more species. In contrast, laboratory $\mathrm{K}$, which also used mycobacterial cytoplasmic extracts in a gel diffusion reaction against a battery of antisera, showed nearly $100 \%$ agreement with the phenetic clustering (Table 4). The reason for the discrepant results between these two laboratories is not readily apparent at present. The results of the two laboratories cannot be directly compared because of differences in method 
Table 7. Distribution of strains by lipid thin-layer chromatographic pattern and phenetic clustering behaviour

\begin{tabular}{|c|c|c|c|c|c|c|c|c|c|c|c|c|}
\hline \multirow{2}{*}{$\begin{array}{c}\text { Cluster } \\
\text { no. }\end{array}$} & \multirow[b]{2}{*}{ Species } & \multirow{2}{*}{$\begin{array}{l}\text { No. of } \\
\text { strains }\end{array}$} & \multicolumn{10}{|c|}{ No. of strains exhibiting lipid pattern } \\
\hline & & & A & B & $\mathrm{C}$ & $\mathrm{D}$ & $\mathrm{E}$ & $\mathrm{F}$ & G & $\mathrm{H}$ & I & $\mathbf{J}^{*}$ \\
\hline I & Mycobacterium smegmatis & 8 & . & . & . & . & . & . & I & . & . & 7 \\
\hline 2 & M.phlei & 2 & . & . & 1 & . & . & . & . & . & $\mathrm{I}$ & . \\
\hline 3 & M. vaccae & 8 & . & . & . & . & . & . & I & . & . & 7 \\
\hline 5 & M. flavescens & 6 & . & 3 & I & . & . & . & . & . & . & 2 \\
\hline 7 & M. thamnopheos & I & . & . & . & . & . & . & . & I & . & . \\
\hline $8 a$ & M. fortuitum & 8 & . & . & 6 & . & . & . & . & . & . & 2 \\
\hline $8 b$ & $M$. peregrinum & 10 & & . & 5 & 2 & & I & . & . & . & 2 \\
\hline $9 a$ & M. abscessus & Io & I & . & . & . & 5 & . & . & . & . & 4 \\
\hline $9 b$ & M. borstelense & 5 & . & . & . & . & & 2 & . & . & . & 3 \\
\hline & Total & 58 & I & 3 & 13 & 2 & 5 & 3 & 2 & I & I & 27 \\
\hline
\end{tabular}

(reflected in choice of media, culture age, use of pellicle or subsurface growth, immunization schedule, strains used to prepare antisera, and actual immunodiffusion methods).

Table 5 records the ability of some of the strains to produce in mice the signs of spinning disease (Penso et al. 1952), of gross disease of internal organs evident to the naked eye and of positive recovery of the infecting organism from organ homogenates plated on egg medium. Evidently most of the path ological changes are due to organisms found in clusters $8 a$ and $9 a$, although $50 \%$ of the strains of Mycobacterium smegmatis (cluster I) were observed to produce some signs of infection in mice.

Laboratory $\mathrm{J}$ subjected many of these mycobacterial strains to the lytic action of six mycobacteriophages. The seven major lytic patterns observed, together with the distribution of the various tested strains in these seven patterns is summarized in Table 6. Forty-five per cent of the strains examined were not lysed by any phage under conditions employed in this study. Phages BK 3 and D-I I are very specific for Mycobacterium smegmatis and $M$. phlei respectively, but phage typing methods must be developed further before they will be useful for differentiation of other species.

Thin-layer chromatographic separation of the ethanol-ether soluble lipids of these mycobacteria (Marks \& Szulga, 1965) has yielded nine distinctive lipid pattern groups (A-I) and one group $(J)$ in which no distinctive lipid pattern was observed (Table 7 ). In contrast to the earlier study (Wayne et al. 197I) in which most of the strains could be classified by lipid pattern, $47 \%$ of the rapid growers in the present study produced a non-diagnostic pattern. Further evaluation of the nine distinctive patterns which were found revealed that several patterns $(\mathrm{C}, \mathrm{F}, \mathrm{G})$ crossed species boundaries, while different strains of some species (clusters $2,5,8 b$ and $9 a$ ) were distributed in several distinctive lipid pattern groups.

\section{DISCUSSION}

The earlier discussions (Wayne et al. 197I) on the permissive philosophy of IWGMT studies and the definition of intracluster 'noise' will not be reiterated here. With the completion of this second international co-operative study, and the pending culmination of four other studies in progress, it is apparent that the early goals of the IWGMT are being met: international agreement on subgeneric classification within the genus Mycobacterium; recognition of the most valuable tests in taxonomic use; and precise definition of those 
selected tests to insure greater uniformity in final test results. This latter facet is now under consideration for a future IWGMT investigation.

Results of the present investigation corroborate the earlier recognition as distinct taxa of species Mycobacterium smegmatis and $M$. phlei (Gordon \& Smith, I953), M. diernhoferi (Bönicke \& Juhasz, I965), M. flavescens (Bojalil et al. 1962) and M. thamnopheos (Aronson, I929). The generic classification of the latter organism has recently been suggested as Nocardia rather than Mycobacterium (Lechevalier, Horan \& Lechevalier, 197I) and the evidence presented by the authors seems valid.

Examination of both pooled and individual results (Fig. I, 2) showed cluster 3 to be a rather homogeneous assemblage of strains containing representative cultures of both $M y c o-$ bacterium vaccae (Bönicke \& Juhasz, 1964) and $M$. parafortuitum (Tsukamura et al. 1965). On the other hand, both laboratories $\mathrm{G}$ and $\mathrm{H}$ (see Fig. $2 g, h$ ) obtained a relatively low intrataxon matching score, reflecting an inordinately high intrataxon noise level for cluster 3 . The observations from these two laboratories might support an earlier report (Tsukamura et al. 1968) that $M$. vaccae and $M$. parafortuitum are two distinct taxa. To resolve this problem a larger assemblage of strains, representative of these two groups, has been included in a current IWGMT study. Should the outcome of that study support the pooled results presented here, then the correct name (and type culture) of the taxon represented as cluster 3 would, by priority, be $M$. vaccae (ATCC I5483) (Bönicke \& Juhasz, I964).

Clusters $8 a$ and $8 b$, in the opinion of the authors, should be considered as a homogeneous assemblage, leaving only the question of specific epithet to be considered. Interestingly, none of the participants was able to corroborate the differences between Mycobacterium fortuitum and $M$. peregrinum described earlier (Bojalil et al. 1962). The epithet 'peregrinum' was established solely on the basis of the variation in acid production from carbohydrates of only one strain of this taxon which then consisted of only two strains! Consideration by the Judicial Commission will be needed to decide on the name for this species. Stanford \& Gunthorpe (I969) have presented reasons why the organisms in cluster 8 should be called $M$. ranae rather than $M$. fortuitum, while Runyon (1972), after a poll of the members of the IWGMT, presented arguments for retention of the epithet 'fortuitum' and requested an opinion of the Judicial Commission. As indication of our majority support of Runyon's proposal, we suggest that cluster 8 organisms be referred to as $M$. fortuitum, with further infra-subspecific definition effected by lipid pattern and sero-agglutination (Jenkins, Marks \& Schaefer, 197I).

In the case of cluster 9 , fusion of subgroups $a$ and $b$ occurs between intertaxon matching scores of 80 and $85 \%$ (see Fig. I $b$ ), and only one participant, using tests unique to his laboratory, was able to show a clear distinction between clusters $9 a$ and $9 b$ (see Fig. $2 h$ ). In view of the supporting evidence from lipid patterns and serological studies (Stanford \& Beck, I969; Jenkins et al. 197I) that these two taxa are very similar, we would propose that $9 a$ and $9 b$ be classified together at present, under the legitimate, specific name Mycobacterium chelonei (Stanford \& Beck, 1969). Stanford, Gunthorpe, Pattyn \& Portaels (1972) have recently shown the type strain of $M$. chelonei (NCTC 946) to be identical with strains in cluster $9 b$, and, in contrast to our strains (Table 2), a number of their isolates were recovered from patients with disease. Since two distinct subgroups of this taxon can be identified by tests $17,22,23,26,27$ and 28 (see Table r), we propose the designation of two subspecies of the taxon: $M$. chelone $i$ subsp. chelonei (type culture NCTC946) and $M$. chelonei subsp. abscessus (type culture ATCC I9977). 
The authors are deeply indebted to the following individuals without whose assistance the project could not have been realized: Dr E. F. Lessel of ATCC for preparation and distribution of lyophilized strains; Mr E. A. Warburton, Veterans Administration Western Research Support Center, Sepulveda, California, who in collaboration with Dr L. G. Wayne, prepared the programs and performed the computer analyses.

\section{REFERENCES}

Aronson, J. D. (1929). Spontaneous tuberculosis in snakes, n.sp. Mycobacterium thamnopheos. Journal of Infectious Diseases 44, 21 5-223.

Bojalil, L. F., Cerbon, J. \& Trujillo, A. (1962). Adansonian classification of mycobacteria. Journal of General Microbiology 28, 333-346.

BöNICKE, R. \& JUHASZ, S. E. (1964). Beschreibung der neuen Species, Mycobacterium vaccae n.sp. Zentralblatt fiir Bakteriologie, Parasitenkunde, Infektionskrankheiten und Hygiene (Abteilung I. Originale) 192, I 33-135.

BöNICKE, R. \& JUHASZ, S. E. (1965). Mycobakterium diernhoferi n.sp., eine in der Umgebung des Rindes häufig vorkommende neue Mycobacterium-Species. Zentralblatt für Bakteriologie, Parasitenkunde, Infektionskrankheiten und Hygiene (Abteilung I. Originale) 197, 292-294.

BuHler, V. B. \& POLLAK, A. (1953). Human infection with atypical acid-fast organisms. American Journa of Clinical Pathology 23, 363-374.

Crow, H. E., King, C. T., Smith, C. E., Corpe, R. F. \& Stergus, I. (1957). A limited clinical, pathologic, and epidemiologic study of patients with pulmonary lesions associated with atypical acid-fast bacilli in the sputum. American Review of Tuberculosis 75, 199-222.

Gordon, R. E. \& SMITH, M. M. (1953). Rapidly growing acid-fast bacteria. I. Species description of Mycobacterium phlei Lehmann and Neumann and Mycobacterium smegmatis (Trevisan) Lehmann and Neumann. Journal of Bacteriology 66, 41-48.

Jenkins, P. A., Marks, J. \& Schaefer, W. B. (197I). Lipid chromatography and seroagglutination in the classification of rapidly growing mycobacteria. American Review of Respiratory Disease 103, 179-187.

Kubica, G. P., Silcox, V. A., Kilburn, J. O., Smithwick, R. W., Beam, R. E., Jones, W. D., Jun. \& StOTtMeier, K. D. (1970). Differential identification of mycobacteria. VI. Mycobacterium triviale Kubica sp.nov. International Journal of Systematic Bacteriology 20, I6I-I74.

Kwapinski, J. B. G., Alcasid, A. \& Palser, H. (1970). Serologic relationships of endoplasm antigens of saprophytic mycobacteria. Canadian Journal of Microbiology $\mathbf{1 6}, 87 \mathrm{I}-876$.

Lechevalier, M. P., Horan, A. C. \& Lechevalier, H. (1971). Lipid composition in the classification of Nocardiae and Mycobacteria. Journal of Bacteriology I05, 31 3-318.

MARKS, J. \& SzUlGA, T. (1965). Thin-layer chromatography of mycobacterial lipids as an aid to classification; technical procedures: Mycobacterium fortuitum. Tubercle (London) 46, 400-4I I .

Penso, G., Castelnuovo, G., Guadiano, A., Princivalle, M., Vella, L. \& Zampieri, A. (1952). Studi e ricerche sui micobatteri. VIII. Un nuovo bacillo tubercolare: il Mycobacterium minetti n.sp. Studio microbiologico e patogenetico. Rendiconti Istituto Superiore di Sanità 15, 49I-548.

Runyon, E. H. (1959). Anonymous mycobacteria in pulmonary disease. Medical Clinics of North America 43, $273-290$.

RunYON, E. H. (1965). Pathogenic mycobacteria. Advances in Tuberculosis Research 14, 235-287.

RunYoN, E. H. (1972). Conservation of the specific epithet fortuitum in the name of the organism known as Mycobacterium fortuitum da Costa Cruz. Request for an opinion. International Journal of Systematic Bacteriology 22, 50-5I.

SNeAth, P. H. A. \& Cowan, S. T. (1958). An electro-taxonomic survey of bacteria. Journal of General Microbiology I9, 551-565.

StANFord, J. L. \& BeCK, A. (1968). An antigenic analysis of the Mycobacteria, Mycobacterium fortuitum, Myco. kansasii, Myco. phlei, Myco. smegmatis and Myco. tuberculosis. Journal of Pathology and Bacteriology 95, 13 I-I 39 .

StANFORD, J. L. \& BeCK, A. (I969). Bacteriological and serological studies of fast growing mycobacteria identified as Mycobacterium friedmannii. Journal of General Microbiology 58, 99-106.

STANFORD, J. L. \& GUNTHORPE, W. J. (1969). Serological and bacteriological investigation of Mycobacterium ranae (fortuitum). Journal of Bacteriology 98, 375-383. 
Stanford, J. L., Gunthorpe, W. J., Pattyn, S. R. \& Portaels, F. (1972). Studies on Mycobacterium chelonei. Journal of Medical Microbiology 5, I71-I82.

TakeYa, K., Nakayama, Y. \& Muraoka, S. (1970). Specificity in skin reaction to tuberculin protein prepared from rapidly growing mycobacteria and some nocardia. American Review of Respiratory Disease I02, 982-986.

TsuKamura, M. (1966). Adansonian classification of mycobacteria. Journal of General Microbiology 45, 253-273.

Tsukamura, M., Mizuno, S. \& Tsukamura, S. (I968). Classification of rapidly growing mycobacteria. Japanese Journal of Microbiology 12, I 5 I-I 66.

Tsukamura, M., Toyama, H. \& Mizuno, S. (1965). Mycobacterium parafortuitum: a new species. (In Japanese.) Medicine and Biology 7o, 232-235.

WAYNE, L. G. (1967). Selection of characters for an Adansonian analysis of mycobacterial taxonomy. Journal of Bacteriology 93, I382-1 39I.

Wayne, L. G., Dietz, T. M., Gernez-Rieux, C., Jenkins, P. A., KäPpler, W., Kubica, G. P., Kwapinski, J. B. G., Meissner, G., Pattyn, S. R., Runyon, E. H., Schröder, K. H., Silcox, V. A., Tacquet, A., TsuKAMURA, M. \& WolinsKY, E. (197I). A co-operative numerical analysis of scotochromogenic slowly growing mycobacteria. Journal of General Microbiology 66, 255-27 I.

WAYNE, L. G., DoubeK, J. R. \& DiAz, G. A. (1967). Classification and identification of mycobacteria. IV. Some important scotochromogens. American Review of Respiratory Disease 96, 88-95.

Wayne, L. G., Runyon, E. H. \& Kubica, G. P. (1969). Mycobacteria: a guide to nomenclatural usage. American Review of Respiratory Disease I00, 732-734. 